\title{
IMPLICATIONS OF RADIOCARBON DATES FROM POTTER CREEK CAVE, SHASTA COUNTY, CALIFORNIA, USA
}

\section{Robert S Feranec}

New York State Museum, 3140 Cultural Education Center, Albany, NY 12230, USA. Email: rferanec@mail.nysed.gov.

ABSTRACT. New dates obtained from the bone collagen of mammals from the deposits in Potter Creek Cave, Shasta County, California, USA, show that these fossils were emplaced over the last 30,000 yr. The dates support the assignment of the fauna in the cave to the late Pleistocene and are contemporaneous to the dates obtained from the fauna of Samwel Cave located $5 \mathrm{~km}$ to the north. These new dates do not support previous radiocarbon dates suggesting a Holocene extinction of the extinct bovid Euceratherium collinum, and demonstrate that this and other megafauna were not present in the vicinity after the terminal Pleistocene.

\section{INTRODUCTION}

Excavations in Potter Creek Cave (PCC) in northern California (Figure 1) were initiated in 1902 with the aim of discovering the antiquity of humans in North America (Sinclair 1903, 1907; Payen and Taylor 1976). These and future excavations at PCC yielded numerous fossils of both extant and extinct species (Table 1) (Sinclair 1903, 1905, 1907; Payen and Taylor 1976). From this site, a number of new species were described including such animals as a new Pleistocene vampire bat (Desmodus stocki), the Shasta ground sloth (Nothrotheriops shastensis), and the shrub ox (Euceratherium collinum) (Sinclair 1905, 1907; Hutchison 1967).



Figure 1 Location of Potter Creek Cave $(\mathrm{H})$ in Shasta County, California. Also note location of Samwel Cave to the north.

Another notable site, located just $5 \mathrm{~km}$ to the north, is Samwel Cave (SC). Recent ${ }^{14} \mathrm{C}$ dates on bone collagen showed that the SC fauna was likely deposited during the last glacial maximum (Feranec et al. 2007). Based on the presence of particular extinct species, it was suggested that PCC is slightly older than SC. However, published dates from PCC are all Holocene in age (Taylor 1975; Payen and Taylor 1976). The young dates from PCC have further implications because some of the dates are from extinct fauna, like the shrub ox (E. collinum), which was suspected to have gone extinct during the end-Pleistocene extinction in North America prior to $10 \mathrm{kyr}$ (Barnosky et al. 2004). Therefore, either northern California acted as a refugium for E. collinum and possibly other fauna, or the pub- 
Table 1 Mammalian species list from Potter Creek Cave $(\dagger=$ extinct $)$.

\begin{tabular}{l|l}
\hline Artiodactyla & Chiroptera \\
Bison sp. & Antrozous pallidus \\
Cervus sp. & $\dagger$ Desmodus stocki \\
$\dagger$ Euceratherium collinum & Insectivora \\
Odocoileus hemionus & Scapanus latimanus \\
$\dagger$ Oreamnos americanus & Lagomorpha \\
Ovis sp. & Lepus americanus \\
$\dagger$ Platygonus sp. & Lepus californicus \\
Carnivora & Sylvilagus auduboni \\
$\dagger$ Arctodus simus & Sylvilagus bachmani \\
Bassariscus astutus & Perissodactyla \\
$\dagger$ Canis dirus & $\dagger$ Equus occidentalis \\
Canis latrans & $\dagger$ Equus pacificus \\
Canis lupus & Primata \\
$\dagger$ Panthera leo atrox & Homo sapiens \\
Lynx rufus & Proboscidea \\
Martes americana & $\dagger$ Mammut americanum \\
Mephitis mephitis & $\dagger$ Mammuthus primigenius \\
Mustela frenata & Rodentia \\
Mustela vison & Aplodontia rufa \\
Procyon lotor & Erethizon sp. \\
Puma concolor & \\
Spilogale gracilis & \\
Taxidea sp. & \\
Urocyon cinereoargenteus & \\
Ursus americanus & \\
Vulpes vulpes & \\
\hline
\end{tabular}

lished dates from PCC are suspect. Thus, it is important to accurately determine the chronology of fauna in the PCC deposits. New dates from PCC facilitate a comparison to the chronology of the SC fauna, which ultimately should provide greater insight into the mammal ecology of northern California during the late Pleistocene. Further, these dates will permit an understanding into whether northern California acted as a refugium for E. collinum and possibly other mammalian species.

\section{BACKGROUND}

Potter Creek Cave (PCC) is located within the McCloud limestone along the eastern edge of the McCloud River arm of Lake Shasta, $460 \mathrm{~m}$ above sea level (Figure 1). PCC was discovered in 1878, and excavation of fossil material began in 1902 by the University of California, Berkeley (Sinclair 1903, 1905, 1907). The excavations during the 1902-03 field seasons were done in the Lower Chamber (Figure 2). Pits [4 $\left.\mathrm{ft}^{2}\left(1.22 \mathrm{~m}^{2}\right)\right]$ were excavated in 10-inch $(25.4 \mathrm{~cm})$ layers to a depth of $7.5 \mathrm{~m}$. Seven different layers were identified in the Lower Chamber deposits. The bedrock of the cave floor is overlain in successive order by: stalagmite blocks in clay matrix, soft clay, cemented clay and gravel, clay with fallen limestone, volcanic ash, gravel, and clay and gravel at the surface (Sinclair 1903, 1907). Some specimens from PCC can be assigned to a particular depth from which each was found. From these excavations, nearly 4500 specimens were collected representing at least 78 species, including 56 mammal species (Table 1). Mammals include extinct (e.g. ground sloths, horses, and the short-faced bear) and extant taxa (e.g. black bears, foxes, squirrels, and woodrats). The Entrance Chamber was excavated during the mid-1960s (Figure 2) (Payen and Taylor 1976) and 
some bone material from this chamber was radiocarbon dated in the early 1970s (Taylor 1975; Payen and Taylor 1976).

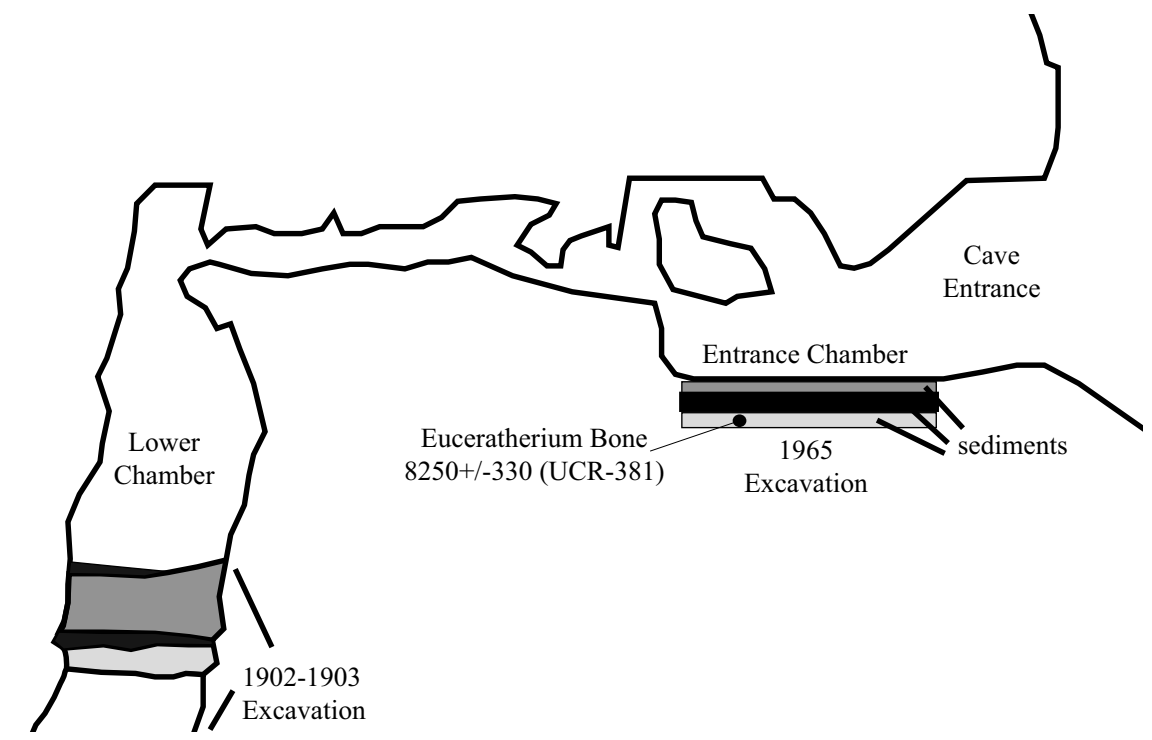

Figure 2 Cross-sectional view of Potter Creek Cave. The specimens dated here come from the Lower Chamber. Figure modified from Payen and Taylor (1976).

\section{METHODS}

For this study, bone samples were obtained from at least 4 different taxa from the vertebrate paleontology collections at the University of California Museum of Paleontology (UCMP). Four specimens from the Lower Chamber of Potter Creek Cave (Figure 2) and 3 specimens from Chamber Two of Samwel Cave were analyzed including both large (i.e. Odocoileus sp., Euceratherium collinum, Felidae) and small (i.e. Spermophilus sp., Rodentia) taxa. In the cave, the analyzed samples were dispersed among other specimens, including that of fauna which is now extinct. Preparation procedures generally follow Brown et al. (1988) and Bronk Ramsey et al. (2004). Samples were first decalcified using $0.5 \mathrm{~N} \mathrm{HCl}$ to obtain collagen, generally for about $24-48 \mathrm{hr}$. Once decalcified, collagen was then gelatinized at $58{ }^{\circ} \mathrm{C}$ for $16 \mathrm{hr}$. The gelatin solution was then filtered to remove any remaining solids. The solution was then ultrafiltered to remove the $30-\mathrm{kD}$ fraction, and the $30-\mathrm{kD}$ fraction was lyophilized. In general, lyophilized collagen appeared similar to a white cotton ball. Graphitization and analysis were conducted at the National Oceanic Sciences Accelerator Mass Spectrometry (NOSAMS) facility. All dates were calibrated using the online CALIB 5.0.2 program (Stuiver et al. 2005).

\section{RESULTS AND DISCUSSION}

Four dates were obtained from small and large mammals from Potter Creek Cave along with 3 additional dates from small mammals at Samwel Cave (Table 2). One of the PCC samples (UCMP 3141), provided a ${ }^{14} \mathrm{C}$ date of $26,100 \pm 160 \mathrm{yr}$ and was beyond calibration limits of the CALIB 5.0.2 program. The other 3 PCC samples ranged from 14,100 to 20,500 cal BP. An E. collinum specimen (UCMP 3111) dated to between 20,000-20,500 cal BP. This is significantly older than a previous date $(8250 \pm 330 \mathrm{yr}$; UCR-381) obtained from an uncataloged UCMP specimen of E. collinum from this cave (Payen and Taylor 1976). 


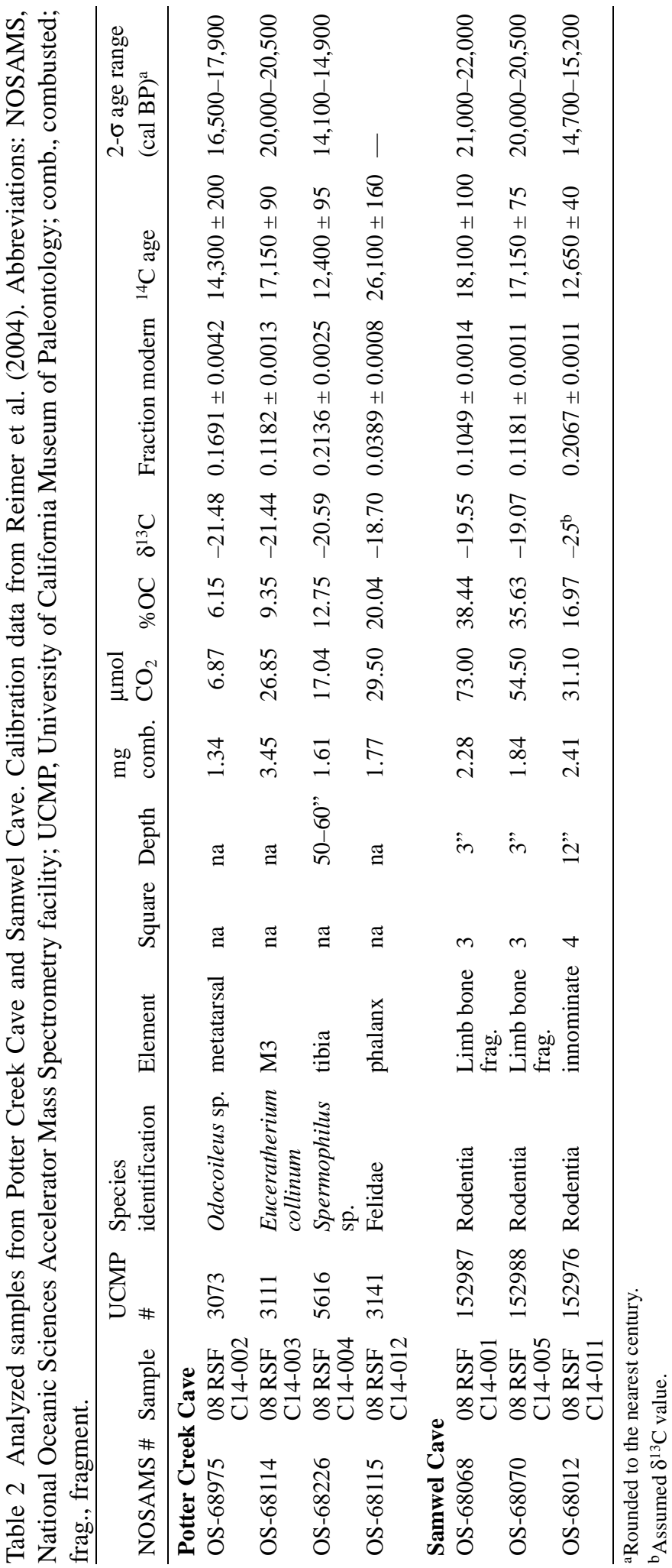


Because of the number of extant and extinct species present in the PCC and SC deposits, both caves were inferred to span the Pleistocene and Holocene, but the PCC fauna was thought to be older (Furlong 1904). Two of the SC specimens ranged from 20,000-22,000 cal BP, and are similar to dates obtained in a previous study (Feranec et al. 2007). A third specimen from SC (UCMP 152976) dated to between 14,700-15,200 cal BP. This specimen shows that the fossil deposits in SC accumulated over a time span of at least $9000 \mathrm{yr}$, and that some of the SC specimens may be younger than previously assumed (Feranec et al. 2007). Even though 1 date from PCC is older than any date obtained from SC and 1 date from SC is younger than any date obtained from PCC, in general, the deposits at $\mathrm{SC}$ and $\mathrm{PCC}$ are contemporaneous.

Working in the Entrance Chamber of PCC, Payen and Taylor (1976) obtained a Holocene date (8250 \pm 330 ; UCR-381) for the extinct bovid Euceratherium collinum. This date is interesting because this species is one of those proposed to have gone extinct before $10 \mathrm{kyr}$, during the North American end-Pleistocene extinction event (Barnosky et al. 2004). A Holocene date either suggests that northern California acted as a refugium for the species, or that the date is unreliable, possibly due to contamination. The results presented here and those previously published for SC (Feranec et al. 2007) do not support a Holocene extinction for E. collinum. Of the 12 dates recently obtained from material in these sites (this study and Feranec et al. 2007), none are Holocene in age. Further, dates on 2 E. collinum specimens (UCMP 3111, UCMP 9128) from both localities date to well before the Holocene, between 19,200-20,500 cal BP. Recent advances in techniques to extract and analyze bone collagen have improved the accuracy of dates (Brown et al. 1988; Hedges and Law 1989; Hedges and van Klinken 1992; Bronk Ramsey et al. 2004). Since these techniques postdate the analysis for the Holocene-dated E. collinum specimen, the likely explanation for the anomalously young date is contamination from young carbon (Hedges and Law 1989; Hedges and van Klinken 1992), a flawed sampling protocol (Brown et al. 1988; Law and Hedges 1989; Bronk Ramsey et al. 2004), or both. Thus, the previously reported Holocene age of the extinct megafaunal shrub ox is deemed unreliable.

\section{ACKNOWLEDGMENTS}

I would like to thank P Holroyd for permission to sample and analyze these specimens. I thank $\mathrm{J}$ Blois and E A Hadly who provided comments that improved the manuscript. Funding was provided by an NY State Museum Research grant.

\section{REFERENCES}

Barnosky AD, Koch PL, Feranec RS, Wing SL, Shabel AB. 2004. Assessing the causes of Late Pleistocene extinctions on the continents. Science 306(5693):70 5.

Bronk Ramsey C, Higham T, Bowles A, Hedges R. 2004. Improvements to the pretreatment of bone at Oxford. Radiocarbon 46(1):155-63.

Brown TA, Nelson DE, Vogel JS, Southon JR. 1988. Improved collagen extraction by modified Longin method. Radiocarbon 30(2):171-7.

Feranec RS, Hadly EA, Blois JL, Barnosky AD, Paytan A. 2007. Radiocarbon dates from the Pleistocene fossil deposits of Samwel Cave, Shasta County, California, USA. Radiocarbon 49(1):117-21.

Furlong EL. 1904. An account of the preliminary excavations in a recently explored Quaternary cave in Shasta County, California. Science 20(497):53-5.
Hedges REM, Law IA. 1989. The radiocarbon dating of bone. Applied Geochemistry 4(3):249-53.

Hedges REM, van Klinken GJ. 1992. A review of current approaches in the pretreatment of bone for radiocarbon dating by AMS. Radiocarbon 34(3):279-91.

Hutchison JH. 1967. A Pleistocene vampire bat (Desmodus stocki) from Potter Creek Cave, Shasta County, California. PaleoBios 3:1-6.

Law IA, Hedges REM. 1989. A semi-automated bone pretreatment system and the pretreatment of older and contaminated samples. Radiocarbon 31(3):247-53.

Payen LA, Taylor RE. 1976. Man and Pleistocene fauna at Potter Creek Cave, California. Journal of California Anthropology 3(1):51-8.

Reimer PJ, Baillie MGL, Bard E, Bayliss A, Beck JW, Bertrand CJH, Blackwell PG, Buck CE, Burr GS, Cutler KB, Damon PE, Edwards RL, Fairbanks RG, 
Friedrich M, Guilderson TP, Hogg AG, Hughen KA, Kromer B, McCormac G, Manning S, Bronk Ramsey C, Reimer RW, Remmele S, Southon JR, Stuiver M, Talamo S, Taylor FW, van der Plicht J, Weyhenmeyer CE. 2004. IntCal04 terrestrial radiocarbon age calibration, 0-26 cal kyr BP. Radiocarbon 46(3):1029-58.

Sinclair WJ. 1903. A preliminary account of the exploration of the Potter Creek Cave, Shasta County, California. Science 17(435):708-12.

Sinclair WJ. 1905. New mammalia from the Quaternary caves of California. University of California Publications in Geology 4:145-61.

Sinclair WJ. 1907. The exploration of the Potter Creek Cave. University of California Publications in American Archaeology and Ethnology 2:1-27.

Stuiver M, Reimer PJ, Reimer RW. 2005. CALIB 5.0 [WWW program and documentation]. URL: http:// calib.qub.ac.uk/calib/.

Taylor RE. 1975. UCR radiocarbon dates II. Radiocarbon 17(3):396-406. 